\title{
FLUE-CURED TOBACCO DEVELOPMENTS UNDER THE AAA
}

\author{
Joseph G. KNapp* and L. R. Paramore $†$
}

Flue-cured tobacco like cotton has often been produced under the vestiges of the plantation system, and in fact is frequently produced in connection with cotton. ${ }^{1}$ It is a cash crop of high acre value with the speculation incident thereto. ${ }^{2}$ It is produced under conditions of high cost-not infrequently amounting to more than $\$ 100$ per acre. Much labor is required, and the "cropper-tenant" system under which the landlord "furnishes" everything but the labor and half the fertilizer has flourished. The tobacco farmer and cropper like the cotton farmer and cropper has generally paid heavy toll to the supply merchant who has supplied goods and fertilizer for "'making" the crop at "time money rates" which have often been more than $3^{\circ}$ percent per annum..$^{3}$

The weak marketing position of flue-cured growers has been stressed by many writers. Dr. T. J. Woofter, in his book The Plight of Cigarette Tobacco states: "Flue-cured tobacco is produced by thousands of farmers many of whom are tenants and Negroes. They are in a weak marketing position because of debts maturing when the crop is cured. This weakness is accentuated by the fact that tobacco, to be held, must be redried soon after curing. While tobacco is a high per acre value crop, the costs, especially the labor costs, are also high, and these costs (per pound) tend, within limits, to fluctuate inversely with the yield per acre. Furthermore, the quality

- B.S., I922, M.A., 1923, University of Nebraska; Ph.D., I929, Stanford University. Member of staff, Institute of Economics, I926-1929, Associate Agricultural Economist, in charge of agricultural tharketing investigations, North Carolina State College since 1929. Author: The Hard Winter Wheat Pool-An Experiment in Agricultural Marketing Integration (University of Chicago) 1933; co-author, with Dr. E. G. Nourse: The Coopperative Marketing of Livestock (Brookings Institution) 1931. [Since the submission of this article, Professor Knapp has been appointed Senior Agricultural Economist, Coöperative Division, Farm Credit Administration.-Ed.]

† B.S., 1931, North Carolina State College. Assistant Extension Economist, North Carolina State College. Appreciation for helpful assistance is here expressed to Dr. G. W. Forster, Head of the Department of Agricultural Economics, North Carolina State College, and to Mr. E. Y. Floyd, Tobacco Extension Specialist, North Carolina State College, in charge of the Tobacco Adjustment Program in North Carolina.

1 The social condition of flue-cured tobacco growers has been indicated to a certain extent in the article by Dr. Rupert B. Vance, Human Factors in the South's Agricultural Readjustment, supra, p. 259, which considered more specifically the problems of cotton growers.

2 The following comparison is of interest in this connection. In 1930 the total acreage of $2,111,600$ acres of tobacco (all types) had a farm value of $\$ 212,467,000$, while $45,091,000$ acres of cotton had a farm value of $\$ 659,032,000$.

${ }^{2}$ See Wooten, The Credit Problems of North Carolina Farmers, N. C. Agr. Exper. Sta. Butc. $27 x$ (1930) 13. 
of the product and hence the price, also varies inversely with the yield so that the farmer never knows exactly what he is producing, what the demand for his product is likely to be, or what his chances for profit are. With these handicaps and the tendency to over-produce, the farmer is in a very weak marketing position."4

\section{Thirteen Years of Discontent}

For the past thirteen years flue-cured tobacco growers have been generally dissatisfied with prices. ${ }^{5}$ When farm prices of flue-cured tobacco fell from approximately 45 cents per pound in 1919 to approximately $2 \mathrm{r}$ cents in 1920 , the farm value of the crop decreased from $\$ 213,651,000$ to $\$ 132,440,000$, and much grumbling was heard from farmers. Many owners lost their farms, and tenants were placed on decidedly lower standards of living. Supply merchants were unable to collect bills, and many were forced out of business. The farmers blamed much of the difficulty on the auction method of marketing which, it was claimed, put them at the mercy of the big tobacco companies. Aided by the philosophy of Aaron Sapiro the farmers made a direct attempt to revolutionize the marketing system by forming the Tri-State Tobacco Association early in 1922. The purposes of the association appeared to meet the demands of farmers, but the aims did not materialize. Lack of continuous support from farmers due to management methods which impaired confidence, and opposition from the tobacco companies and auction markets so handicapped the association that it was forced into the hands of a receiver in June, 1926. The Tri-State Association proved to be just another episode in the history of flue-cured tobacco which was significant chiefly in showing the extent of the problem. ${ }^{8}$

From the standpoint of the farmer the year 1927 was the best year since $x 919 .{ }^{7}$ In $193^{\circ}$ the annual value plunged approximately 30 million dollars. This was followed in I93 by a further decline in value amounting to approximately 47 million dollars, or a decrease of $4^{6}$ per cent. The season of 1932 brought no relief when measured in terms of total farm value. It is true that average farm prices increased from 8.8 cents in I93I to II. 6 cents in 1932, but because of a short crop the position of the tobacco farmers was not improved. The 1932 crop sold for 14.5 million dollars less than the I93I crop, a decline in farm value of 26 per cent.

- Woofter, The Plight of Cigarette Tobacco (193x) 24.

- However, in some years during this period, flue-cured tobacea has been relatively a profitable crop.

-See Hanna, Agricultural Coöperation in Tobacco, supra, p. 3I5, for the history of this assocjation.

? The annual farm value of flue-cured tobacco from 1913 through 1932 is here given as shown by the United States Department of Agriculture figures:

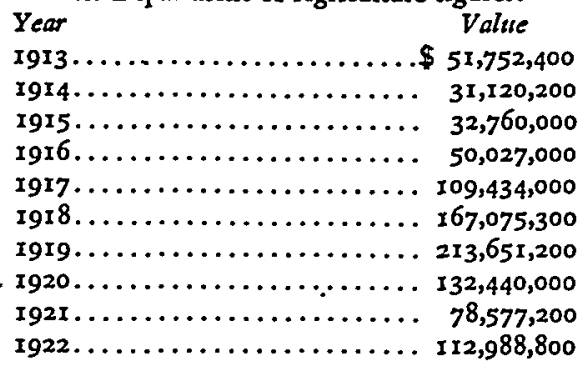

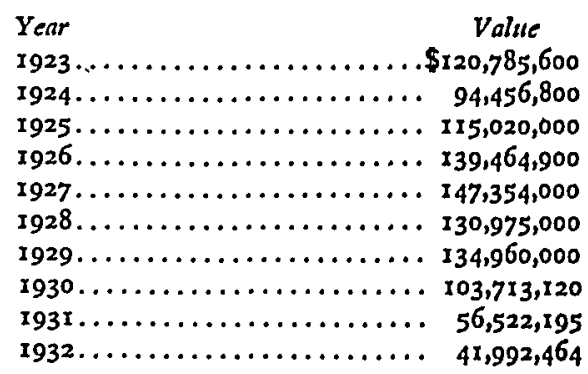


With the precipitous decline in tobacco prices in 1930, growers with the support of the Federal Farm Board again started a movement for coöperative marketing. In South Carolina an association was set up which operated for one year. In North Carolina and Virginia, after considerable organization effort, it was decided that ample volume was not available to insure the success of operation. During the I93I and 932 marketing seasons farmers were apathetic to organization. Blind hope had taken the place of militant discontent.

\section{Stattstical Position of Flue-Cured Tobacco}

Before going further it is necessary to consider the importance of flue-cured tobacco in the tobacco industry, as a basis for understanding the conditions in the summer of r933. Flue-cured tobacco is produced in specialized areas of which the major portion is located in five states. During the five-year period, 1928 to 1932 , the distribution of the farm value by states was: North Carolina $7 \mathrm{r} .9$ per cent; South Carolina 9.9 per cent; Virginia 8.7 per cent; Georgia 8.9 per cent; and Florida .6 per cent.

Tobacco is divided by the United States Department of Agriculture into eight classes and twenty-five different types, many of which are enough unlike to be classed as separate commodities. Flue-cured tobacco, which is largely used for cigarettes, is by far the most important class. ${ }^{8}$ In $193^{\circ}$ flue-cured tobacco represented 53.4 per cent of the total tobacco acreage in the United States; 52.5 per cent of the total production, and 48.8 per cent of the total value. The following figures indicate, by five-year intervals, the importance of flue-cured tobacco in the industry since rgr3.

The Position of Flue-Cured Tobacco in the Tobacco Industry rgr3 to 1932*

\begin{tabular}{|c|c|c|c|c|c|c|c|c|c|}
\hline YeARs & 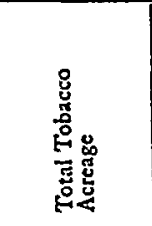 & 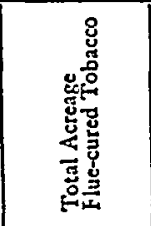 & 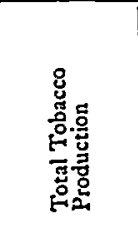 & 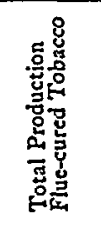 & 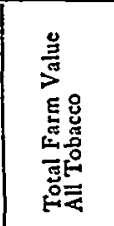 & 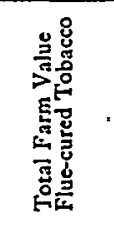 & 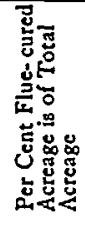 & 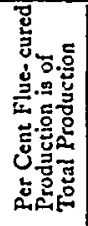 & 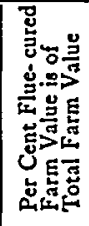 \\
\hline & & & \multicolumn{2}{|c|}{ (In million pounds) } & \multicolumn{2}{|c|}{ (In million dollars) } & & & \\
\hline 1913 to 1917 . & $1,348,140$ & 471,100 & $1,090.6$ & 248.8 & $\$ 158.1$ & $\$ 55.0$ & 34.9 & 22.8 & 34.8 \\
\hline 1918 to 1922 . & $1,699,220$ & 771,520 & $1,330.3$ & 369.5 & 319.3 & 140.9 & 45.4 & 27.7 & 44.1 \\
\hline 1923 to 1927 . & $1,698,460$ & 852,430 & $1,327.8$ & 460.0 & 247.5 & 123.0 & 50.2 & 34.6 & 49.9 \\
\hline $\begin{array}{l}1928 \text { to } 1932 \text {. } \\
\text { Average for }\end{array}$ & $1,882,360$ & $1,002,180$ & $1,439.1$ & 635.0 & 203.2 & 93.3 & 53.2 & 44.1 & 45.9 \\
\hline 20-year period & $1,657,045$ & 774,307 & $1,297.0$ & 428.0 & 232.0 & 103.2 & 46.7 & 33.0 & 44.5 \\
\hline
\end{tabular}

- Data derived from United States Department of Agriculture publications.

The acreage and production of flue-cured tobacco has increased consistently over the twenty-year period beginning in 1913. The calculations are based on five-year averages which eliminate variations due to poor crop years. While the acreage and

- The location of the chief flue-cured tobacco producing arcas in the Unitted States is indicated on the map, supra, p. 296. 
production increased throughout the period, farm value, as already noted, did not. Although the acreage of flue-cured tobacco increased relative to all tobacco for the five-year period (1928-1932) the farm value of flue-cured tobacco relative to all tobacco fell off.

Two main factors have been largely responsible for the steady increase in the production of flue-cured tobacco; increased domestic consumption and increased exports.

In Ig0o the per capita consumption of cigarette tobacco in the United States was approximately 2.65 ounces. By the year 1910 this had risen to 5.3 ounces; by 1915 , to Io.66 ounces; by 1920 to 24.8 ounces and by 1929 to 44 ounces. The peak in per capita consumption was reached in 1929 , and since that time there has been a slight decline in the per capita use of cigarette tobacco. This decrease has been commonly attributed to the effect of the depression, but it may be that the saturation point has been reached unless new users can be found. ${ }^{9}$

Exports increased steadily from 1923 to 1930 except for two years, 1924 and 1926. In the year 193I exports fell off 34 per cent. During the ten-year period, 1923 to 1932 , the total exports represented $5 \times 1.8$ per cent of the total production. These figures indicate the great importance of exports in the flue-cured industry.

\begin{tabular}{|c|c|c|c|}
\hline YeAR & $\begin{array}{l}\text { Total Exports of } \\
\text { Flue-cured Tobacco } \\
\text { (In million pounds) }\end{array}$ & $\begin{array}{l}\text { Total Production of } \\
\text { Flue-cured Tobacco } \\
\text { (In million pounds) }\end{array}$ & $\begin{array}{c}\text { Per Cent Exports } \\
\text { are of } \\
\text { Production }\end{array}$ \\
\hline 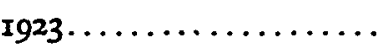 & 266.0 & $5^{80.7}$ & 45.8 \\
\hline$x 924 \ldots \ldots \ldots \ldots \ldots \ldots$ & $207 \cdot 5$ & $437 \cdot 3$ & $47 \cdot 4$ \\
\hline $1925 \ldots \ldots \ldots \ldots \ldots \ldots$ & 324.4 & $575 . x$ & 56.4 \\
\hline $\begin{array}{l}r 926 \ldots \ldots \ldots \ldots \ldots \ldots \ldots \\
\text { rg27 } \ldots \ldots \ldots \ldots \ldots \ldots \ldots\end{array}$ & $\begin{array}{l}288.7 \\
328.9\end{array}$ & $\begin{array}{l}560.1 \\
718.8\end{array}$ & $\begin{array}{l}51.5 \\
45.8\end{array}$ \\
\hline rg28 $\ldots \ldots \ldots \ldots \ldots \ldots$ & 413.9 & 739.1 & 56.0 \\
\hline 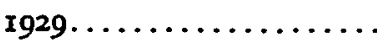 & 429.9 & 749.8 & $57 \cdot 3$ \\
\hline 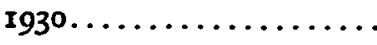 & 432.7 & $864 \cdot 3$ & 50.1 \\
\hline 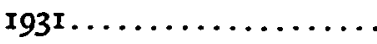 & 285.5 & 669.2 & 42.7 \\
\hline $1932 \ldots \ldots \ldots \ldots \ldots \ldots$ & 270.0 & 376.2 & 71.8 \\
\hline Áverage $\ldots \ldots \ldots \ldots$ & 324.8 & $627 . x$ & $5 x .8$ \\
\hline
\end{tabular}

A more general picture of the flue-cured tobacco industry for the period 1920 to 1932 is given in the following series of index numbers based on the year 1926 .

\footnotetext{
- The recent demand for reduction of the federal excise tax on tobacco products has been based on the theory that lower taxes would permit lower prices to consumers of tobaceo products and that increases in consumption would follow decreased prices. The theory would be valid (granted that retail prices were considerably lowered) if tobacco were out of reach of consumers' ability and willingness to pay, and if the demand for flue-cured tobacco products was not inelastic, a condition where consumers are not responsive to small changes in prices.
} 


\begin{tabular}{|c|c|c|c|c|}
\hline Year & Supply & Disappearance & Farm Prices & $\begin{array}{l}\text { "Big Four" } \\
\text { Net Earnings }\end{array}$ \\
\hline 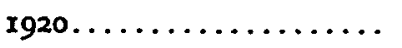 & 92 & 82 & 82 & 57 \\
\hline Ig2I................. & 84 & 75 & 85 & 72 \\
\hline $1922, \ldots \ldots \ldots \ldots \ldots \ldots$ & 83 & 74 & II3 & 80 \\
\hline $1923 \ldots \ldots \ldots \ldots \ldots \ldots$ & IOI & 100 & 87 & 79 \\
\hline x $924 \ldots \ldots \ldots \ldots \ldots \ldots$ & 90 & 82 & 88 & 88 \\
\hline $1925 \ldots \ldots \ldots \ldots \ldots \ldots$ & 102 & 105 & $7^{8}$ & 97 \\
\hline 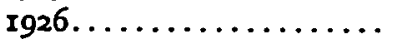 & 100 & 100 & 100 & 100 \\
\hline 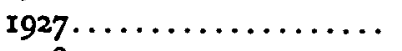 & 106 & 112 & 83 & 104 \\
\hline $1928 \ldots \ldots \ldots \ldots \ldots \ldots$ & II8 & 129 & 69 & 108 \\
\hline Ig29................. & 123 & 134 & 71 & 122 \\
\hline r930................. & 134 & 142 & $5^{6}$ & I49 \\
\hline I93r................ & 122 & 108 & 33 & I57 \\
\hline 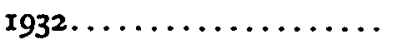 & 99 & I03 & 45 & 148 \\
\hline
\end{tabular}

Computed from data of U. S. Department of Agriculture, except for "Big Four' Net Earnings" which were available in trade publications.

These index numbers show the mounting supply and increasing total consumption as shown by "disappearance" through 1930; the continuous growth of company earnings and the irregular decline in farm prices. ${ }^{11}$ A more detailed view of the flue-cured industry during the years 1930 , 193 I and 1932 and in the summer of 1933 is shown by the following table:

\begin{tabular}{|c|c|c|c|c|c|c|}
\hline \multirow[t]{2}{*}{ Year } & $\begin{array}{l}\text { Total } \\
\text { Produc- } \\
\text { tion }\end{array}$ & $\begin{array}{l}\text { Total } \\
\text { Supply }\end{array}$ & $\begin{array}{c}\text { Total } \\
\text { Disap- } \\
\text { pearance }\end{array}$ & \multirow[t]{2}{*}{$\begin{array}{l}\text { Stocks } \\
\text { July I }\end{array}$} & $\begin{array}{l}\text { Farm } \\
\text { Value }\end{array}$ & $\begin{array}{c}\text { "Big Four" } \\
\text { Net Earnings" } \\
\text { (Calendar Year) }\end{array}$ \\
\hline & \multicolumn{3}{|c|}{ (Million Pounds) } & & \multicolumn{2}{|c|}{ (Millton Dollars) } \\
\hline $\begin{array}{l}1930 \ldots \ldots \\
1931 \ldots \ldots\end{array}$ & $\begin{array}{l}864.3 \\
669.2\end{array}$ & $\begin{array}{l}x, 463.6 \\
x, 346.0\end{array}$ & $\begin{array}{l}786.8 \\
600.8\end{array}$ & $\begin{array}{l}599.3 \\
676.8\end{array}$ & $\begin{array}{r}103.7 \\
56.5\end{array}$ & $\begin{array}{l}105.2 \\
\text { II0.6 }\end{array}$ \\
\hline $32 \ldots \ldots$ & 376.2 & $1,121.3$ & 543.I & 745.2 & 42.0 & 104.6 \\
\hline r933..... & $591.2 *$ & $\ldots$ & $\ldots$ & $57^{8.2}$ & $\cdots$ & $57 \cdot 7$ \\
\hline
\end{tabular}

- Estimated (July I) U. S. Department of Agriculture. The final figure, 708.5, greatly changed the statistical situation.

These figures support the contention of the growers that conditions were ruinous. Within two years the total farm value of flue-cured tobacco fell approximately $\$ 62$,$\infty 00,000$, or $\$ 20,000,000$ more than the 1932 value of the crop. The burden on the

20 "Big Four" is a term commonly employed to refer to the American Tobacca Co., Liggett \& Myers Tobacco Co., P. Lorillard Co., and R. J. Reynolds Tobacco Co. The net earnings of these companies were selected as a basis for comparing the financial status of the processing with that of the producing branches of the industry because of the fact that they represent the largest purchasers of flue-cured tobacco for domestic manufacture. Other types of tobacco, however, are employed in their products, and any statement as to their profits must, of course, be regarded as reflecting that and other factors in the industry distinct from the market prices of flue-cured tobacco.

11 W. G. Finn of the Agricultural Adjustment Administration in the hearings on the Flue-cured Tobacco Marketing Agreement, Sept. 21, 1933, presented data to show that, when farmers' gross receipts for all types of tobacco are added to the profits of 34 leading manufacturers, 70 per cent of that toonl in 1923 represented farmers' gross receipts, while by 1932 this percentage had fallen to 32 per cent.

${ }^{21}$ See note 10, supra. 
growers was not lightened by knowledge that in those two years the net earnings of the tobacco companies showed no decline. During these three years, 1930, I93 $\mathrm{x}$ and 1932, total production of flue-cured tobacco diminished appreciably, as did total supply. Total disappearance (exports and domestic consumption) also fell off. Stocks on hand by domestic manufacturers as of July, however, showed increases each year. Because of the light 1932 crop, 1933 stocks had fallen in July to 578.2 million pounds, a condition which augured a more favorable price condition for 1933 in view of the prospective 1933 crop which was estimated at that time at $59 \mathrm{r} .2$ million pounds.

\section{First Steps in the Flue-Cured Program}

The Agricultural Adjustment Act was passed on May 12, 1933, for the purpose of establishing and maintaining "such balance between the production and consumption of agricultural commodities, and such marketing conditions therefor, as will reëstablish prices to farmers at a level that will give agricultural commodities a purchasing power with respect to articles that farmers buy, equivalent to the purchasing power of agricultural commodities in the base period."13 The base period for tobacco was from August, 19Ig, through July, I929; for all other commodities listed in the Act, from August, I909, through July, rgr4.

Under the Act provision was made for reduction in production through rental or benefit payments to producers who would coöperate in a reduction program. ${ }^{14}$ Other provisions of the Act provided for marketing agreements between the Secretary of Agriculture and "processors, associations of producers, and others engaged in the handling, in the current of interstate or foreign commerce of any agricultural commodity or product thereof. ..."15 and for the issuance of licenses by the Secretary of Agriculture, "as may be necessary to eliminate unfair practices or charges that prevent or tend to prevent the effectuation of the declared policy and the restoration of normal economic conditions" in handling of agricultural products in interstate and foreign commerce. ${ }^{16}$ Funds for carrying on the program were to be derived from processing taxes.

A Tobacco Section was set up soon after the Agricultural Adjustment Administration (AAA) began to function, and work was begun on ways and means to help the tobacco grower under the provisions of the Act. Dr. G. W. Forster, Head of the Department of Agricultural Economics of North Carolina State College, was called to Washington early in July to prepare a preliminary program for flue-cured tobacco. Dr. Forster's plan, which was tentative, in nature, provided for a system of three payments to those growers who would agree to reduce their acreage in accordance with the requirements of the AAA. The first payment was to be made after the con-

${ }^{23} 48$ Stat. 32 (1933), 7 U. S. C. A. (Supp.) \$602.

${ }^{14}{ }_{48}^{8}$ Stat. 34 (1933), 7 U. S. C. A. (Supp.) $\$ 608$ (1).

${ }_{4} 8$ Sтат. 34 (1933), 7 U. S. C. A. (Supp.) $\$ 608$ (2).

${ }_{48}^{10} 8$ STAT. 35 (I933), 7 U. S. C: A. (Supp.) $\$ 608$ (3). 
tract had been accepted; the second, upon proof of compliance by the growers; and the third, after the crop had been marketed.

Although the AAA had started its consideration of a production reduction plan the opinion was general that no action would be taken on the matter with reference to the current season. There seemed to be no urgent necessity to plow-up part of the 1933 crop as had seemed imperative for cotton. The attitude of the Tobacco Section was well expressed at the meetings of the American Institute of Coöperation held in Raleigh, July 23-27. ${ }^{17}$ Dr. J. B. Hutson, in charge of the Tobacco Section, took the position that the statistical situation of flue-cured growers was somewhat better than that of producers of other types of tobacco, and for that reason consideration was being given to other tobacco growers first. It was assumed that a reduction program would be worked out for the 1934 crop but that little could be done for the current crop except perhaps through marketing agreements of one form or another. ${ }^{17 *}$ Dean I. O. Schaub, Director of Extension Service for North Carolina, pointed out that flue-cured tobacco growers would welcome suggestions on how they could benefit under the AAA. Dr. Hutson indicated the general possibilities of action for the current crop but held that proposals would have to come from the growers. Dean Schaub's view was that the government should take the lead under the provisions of the Act; Dr. Hutson's view was that a plan, to be effective, would have to come from growers' demands and in fact be a joint plan. Mr. Chester Davis, then Chief of the Production Division of the AAA and now Administrator, amplified Dr. Hutson's attitude by saying: "We want to avoid being placed in a position where we can develop a full grown plan and come out and say to you 'Here it is.' ... We think we are going to go further safely if we do not go too far in front of the army and get shot from behind."

Dean Schaub, although indicating cordial agreement with this view, urged the necessity for action before December I when tobacco growers' commitments are made. Dr. Hutson recognized the need for decision before that date. Dr. Forster

\footnotetext{
17 The discussion which follows is based largely on material which will be available in the Ninth Annual Proceedings of the American Institute of Cooppration, now in press. An entire session was devoted to the problem of the relation of an adjustment program for tobacco to the coöperative marketing of that crop.

17a Dr. Hutson stated: "In starting our work on tobacco some two months ago, we considered the situation with respect to each group of types. We did not proceed far before it was concluded that the situation was far more critical in the case of the cigar group than in the case of the other types. . . The situation with respect to Burley appears to be critical this season. Most other types are somewhat more favorably situated. It will probably not be advisable to develop plans that will arrest the production of any of these types this year. . . . There remains insofar 25 the 1933 crop is concerned the possibility of keeping the surplus off the market through trade agreement or of paying growers to divert it to noncommercial uses. We are of the opinion at present that any plans under which growers would receive payments to withhold any surplus from the market or divert it to non-commercial uses would also provide for an acreage reduction next ycar. . . Later in the discussion which followed the presentation of the paper Dr. Hutson called attention to the fact that "the [flue-cured] crop this year plus the carryover is about equal to or perhaps slightly larger than the crop of last year plus the carry-over from the previous year. Considering the times, considering the exchange and the fact that over half the tobacco is exported, it is, I should say, comparatively favorably situated."
} 
then proposed that county associations of farmers meet to express their sentiments, and Dean Schaub proffered the services of his organization for this purpose.

It will be noted that the sentiment of the farmers was soon expressed, and in no uncertain way.

\section{The Crisis in August and September, r933}

The first rumblings of discontent among flue-cured tobacco growers over the 1933 situation occurred on August I when the Georgia auction markets opened with prices a little higher than obtained in 1932. Protests were filed with the AAA both by growers and state officials. Governor Talmadge wired President Roosevelt, "Tobacco Belt almost dependent on a living price for tobacco this year to avoid disaster." Ten days later the South Carolina markets opened, and the discontent spread northward. As prices continued lower than growers' expectations the stream of protests and resolutions to the AAA grew rapidly. Prices ruling in Georgia and South Carolina caused much uneasiness among North Carolina growers where the markets were scheduled to open on August 29. This anxiety was intensified during the last week in the month by a slump to a new low level in the southern markets. The average price paid up to that time had been about to cents per pound, or approximately 7 cents under the amount generally estimated as "parity" under the provisions of the Agricultural Adjustment Act.

The month of August was a period of mobilization for North Carolina tobacco producers. Early in the month word was given out that there was little prospect of a processing tax being applied on flue-cured tobacco during 1933. According to the newspapers, "The tobacco manufacturers and buyers of the export trade will be expected to raise prices to growers without the compulsion of the processing tax except as a threat for next year." The growers were not willing to leave it to the buyers. They wanted a definite program for raising prices. On August 4, Dr. Forster issued a statement to the effect that the only hope for federal relief was by forming an association. He took the view that a marketing agreement could be worked out between the big companies and organized growers. Many meetings were held by growers in North Carolina towns during the month. Growers argued that they were on the verge of bankruptcy unless the government came to their support as it had done for cotton and wheat growers. Resolutions and protests were abundant.

A general growers' conference, sponsored by a group of tobacco growers with the active support of the influential Raleigh News and Observer, was called to be held in Raleigh on August 3 , two days after the North Carolina opening. ${ }^{18}$ It proved to be of strategic importance. The markets had just opened, and growers were rampant over the low prices for their crop, in view of the fact that general commodity prices, bolstered by the NIRA, had risen. Approximately 2,000 growers

${ }^{23}$ Much of the ground work for the meeting was done by Mr. L. V. Morrill, Jr., of Snow Hill, N. C., who had covered the eastern tobacco belt, exciting tobacco growers to action. 
were present. Although the meeting was orderly, there was a deep undercurrent of fecling, and it was apparent that something had to be done without delay.

A resolution unanimously adopted early in the meeting clearly presented the general attitude of tobacco growers regarding the need for government help. It called upon the Administrator of the AAA, George N. Peek, to take immediate action in aid of the flue-cured tobacco farmers by instituting emergency measures to assure them of a reasonable profit on their product, to wage an effective reduction campaign for the I934 crop, and to take steps necessary to secure the orderly production, marketing, and grading of tobacco under federal supervision. It pledged the coöperation of the assemblage in furtherence of any plan advanced for these ends.

After further spirited discussion, the following resolution was enthusiastically passed: "Be it resolved by the tobacco farmers in mass meeting assembled that the Governor of North Carolina, J. C. B. Ehringhaus, be requested to close every tobacco warehouse. in North Carolina, under his exercise of martial law, and that he keep them closed until the federal government has time to put into effect measures that will raise the price of tobacco to 20 cents average or more, or until the tobacco companies agree of their own accord to raise the price to that level." A committee was appointed to present the resolutions to the Governor, and a further resolution empowered the Chairman to appoint a delegation to go to Washington immediately to represent tobacco growers' interests.

The Governor responded with alacrity. He issued a proclamation declaring a "voluntary marketing holiday." He asked for the coopperation of all concerned "to prevent the impending catastrophe." The Governor also asked the Governors of South Carolina and Virginia to take similar action in their states. Governor Blackwood of South Carolina did so immediately. As the Virginia markets had not opened an official "holiday" was not deemed necessary.

On September I Secretary Wallace announced that the processing tax for fluecured tobacco would be applied October I with the view of securing an acreage reduction of 15 per cent for I934. Governor Ehringhaus commented on the action as follows: "That plan will not cause any change in our plans. Of course, we are interested in 1934 prices but our main concern now is I933 prices." The tobacco holiday movement was widely indorsed by the entire region. One newspaper remarked, "It is said to be the first united action of the three states in an important undertaking since the Civil War."

On September 6, while the tobacco holiday was still in effect, a meeting composed of delegates selected at county mass meetings, was called in Raleigh by Dean Schaub. Dr. Hutson, Chief of the Tobacco Section, was present, as was Governor Ehringhaus and other interested parties. This meeting laid the ground work for a lightning acreage reduction contract sign-up. ${ }^{19}$ The idea developed that if the growers would

"It also resulted in the formation of a skeleton organization ta represent tobacco growers known as the North Carolina Tobacco Association. Three representatives were elected by the delegates selected by the county mass meetings to represent each of the three tobaeco sections of North Carolina. In addition two representatives were elected at large, making a directorship of eleven members. Mr. Claude T. Hall was named President and Mr. Chas. A. Sheffeld, Assistant to Director of Extension, Secretary. 
pledge to reduce the 1934 crop it would be possible for the government to arrange for higher prices for the 1933 crop.

The pledge to reduce acreage which was prepared was a very simple agreement which did not define the terms of the action to be taken by the government. After recitals setting forth the determination by the Secretary of Agriculture to make "rental and/or benefit payments" on flue-cured tobacco and the necessity for coöperation among growers to effectuate the declared policy of the Agricultural Adjustment Act to approach parity prices as rapidly as possible, the agreement provided that the signer ("landowner or landlord"), in 'consideration of the execution of similar agreements by other growers, agreed to sign, upon presentation, a formal agreement with the Secretary to reduce production in an amount to be designated by the Secretary, not to exceed 30 per cent of his average production for the years 1931-1933, in return for payments, the amount and terms of which were to be determined by the Secretary.

The growers encouraged by the leadership of state officials and the promises of the federal government responded enthusiastically to the idea of an acreage reduction sign-up and within a week approximately 95 per cent of the tobacco growers in the flue-cured states had agreed to reduce their next year's crop by 30 per cent.

\section{The Development of the Marketing Agreement}

Just after the tobacco holiday was declared the question arose, how long would it be in effect? Many hoped that the auction markets would be re-opened in a few days for it was felt that the government could force the hands of the tobacco companies into paying higher prices. Gradually the realization developed that the only hope for higher prices lay in the possibility of developing a marketing agreement between the big companies and the government under which the tobacco buyers would pay prices'agreed upon. Growers were assured that if they would sign the preliminary production adjustment contracts the government would improve the present situation. ${ }^{20}$

Immediate steps were taken by the AAA to prepare a marketing agreement to be submitted to the tobacco companies. On September 17 the Governor of North Carolina declared, "It would be disastrous to reopen the markets before the completion of the marketing agreement with the buyers now in process of formation in Washington." At that time the date for ending the holiday was set at September 25, a date which was expected to afford ample time for the settlement of the agreement. For a time, indeed, it appeared that the buyers would accept the agreement

\footnotetext{
${ }^{20}$ Dr. 3. B. Hutson, chief of the Tobacco Section, in a press release issued Sept. II when the campaign for reducing the flue-cured tobacco acreage was formally opened, stated: "We propose to use the authorization given us in these agreements, together with the powets granted to us through the Agricultural Adjustment Act, to bring about a marked improvement in the prices of flue-cured tobacco this season and the two following seasons. We propose to offer flue-cured growers a plan that will enable those who accept it to receive an income from their farms grcater than they would otherwise receive. I can assure growers that the powers granted to us under the Agricultural Adjustment Act will be used forcefully in carrying out this policy."
} 
drawn up by the AAA and submitted to them on September 15, A formal hearing was held on the proposed agreement in Washington on September 21 and 22.

The marketing agreement drafted by the AAA was to continue in effect until terminated by the Secretary of Agriculture. The Secretary was to be empowered "for good cause shown" to terminate it as to any signatory party. Moreover, he was to terminate it "upon request of seventy-five per cent of the Contracting Buyers .. provided the seasons beginning in 1933 and 1934 shall have been closed." In any event the agreement was to terminate "whenever the provisions of the Act authorizing it shall cease to be in effect."

The agreement provided for an Executive Committee of nine individuals "for the purpose of effectuating and enforcing the provisions of this Agreement subject to the approval of the Secretary." Seven of the members were to be named by the contracting buyers, subject to the approval of the Secretary; the other two were to be named by the Secretary. ${ }^{21}$ One of the latter was to be designated as Chairman. It was stipulated that, "All power and any and all action of the Executive Committee shall be subject to the approval of the Secretary."

Under the terms of the agreement the contracting buyers were to agree to pay growers a minimum average price for tobacco bought during the remainder of the r933 season. An average price for future seasons was to be established by the Executive Committee and the Secretary. The agreement also stipulated that the contracting buyers would not raise prices on manufactured flue-cured products over prices obtaining on September 15, I933, "unless the approval of the Executive Committee and of the Secretary" were given. The decision of the Secretary was to be final in case of disagreement between him and the Committee.

In order to carry out the provisions of the contract, weekly minimum prices were to be established for each flue-cured market by sub-committees of three members appointed by the Executive Committee with the approval of the Secretary. The weekly minimum average price for each market was "to be computed with due regard for the character and quality of the tobacco sold and in such a manner that the average price during the entire season" or for the remainder of the current season, "for any particular market shall not be less" than the agreed average price. The weekly prices were to be subject to the approval or modification of the Secretary who could fix them himself if no determination had been made within ten days after the end of any week. The local market committee was to compute the "percentage of the average of actual prices paid during such week on such market, which when added to such average of actual prices, will increase such average of actual prices to such weekly minimum average price." If the average of actual prices paid on a market during a week was less than the weekly minimum average price established for the market, each buyer was to be billed for his share of the difference be-

\footnotetext{
${ }^{21}$ During the hearings on September 21 an objection to this arrangement was made by tobacco growers who felt that the whole nine members should be appointed by the Secretary of Agriculture. See Transcript, Hearings on Fiue-Cured Tobacco Marketing Agreement, AAA, Sept. $21-22$, I 933.
} 
tween the average of actual prices and the market's established weekly minimum average price. The amount paid by each buyer to equalize prices was to be in proportion to his purchases on the market during the week. The buyers' payments were to be transferred to the growers who had entered into a production reduction agreement in proportion to their sales during the week.

The buyers were to maintain systems of accounting accessible to the Secretary, to reflect their business operations accurately. Under the agreement the buyers were to apply for and consent to licensing by the Secretary with the understanding that the licenses would be "subject to terms and conditions not inconsistent with the purpose and effect of this agreement."

This marketing agreement proposed by the government met with considerable opposition from the tobacco companies. Mr. Clay Williams, President of the R. J. Reynolds Tobacco Company, acted as spokesman for the majority of domestic manufacturers. Mr. Williams admitted that the tobacco grower "has not been getting enough for his leaf-tobacco." He said: "Those for whom I speak are anxious that something be worked out in order that the tobacco grower may have a fair price for his product and a fair return upon his labor." He maintained that the tobacco companies welcomed the Act of Congress. with its provision for a processing tax "as having in it some potentiality, at least, for working out the solution of the thing that none of us, through the years, have been able to work out on our own."22 However, the agreement was "insufficient for the purposes for which it was designed" and would destroy the existing tobacco market. He pointed out that it obligated no signatory to buy a single pound of tobacco. ${ }^{23}$

Mr. Williams was of the opinion that the agreement also presented this question: "Whether the companies stay under management free from government control and at liberty to be fast and quick in the operation of their business, respectively, or whether they are to go into a position where nobody in the management of a company can take any action that amounts to anything-the concentration of development, the expansion of the business-without coming to the government and asking permission. That question is presented in this contract." ${ }^{24} \mathrm{He}$ developed the argument at some length that government control might affect the freedom of the companies to advertise. When questioned by Governor Ehringhaus as to how the contract might limit advertising expenditures, Mr. Williams quoted the price control section which would restrict prices of tobacco products to consumers. It seemed to be his belief that if prices were restricted to the level proposed in the contract there would be little revenue available to the companies for advertising. The general views of the tobacco industry were well summed up by Mr. Williams when he said: "... if the Government is going to take control and restrict management in the matters that are essential to the successful management of the business then the

"See Transeript, op. cit. supra note 21, p. 23.

${ }^{22}$ Ibid. p. 26.

${ }^{24}$ lbid. pp. 34-35. 
possibilities and potentialities of this group with respect to what they can offer today are very much restricted beyond those potentialities if the Government isn't going to take control."25

The views of Governor Ehringhaus clearly presented the attitude of the growers:

I believe that the finest opportunity is here presented to the manufacturers and to the export brethren as well to put themselves in a position of impregnability for years to come. Right coöperation between those two groups with those who are speaking for the farmer and the Government authorities will be a big thing for all. All the Government is asking for, and all we wish, is a 'live and let live policy.' You have lived, and lived sumptuously, the manufacturers-and I am not complaining about it, and Heaven knows I don't mean that in any sense of demagoguery, but I mean comparatively speaking--you have madeand I congratulate you for your splendid management-you have made fine profits in the past and the Government is receiving out of this activity every year millions in the way of taxes. The growers at the other end of the line are not receiving anything but the wages of a peon and a slave. That condition cannot be permitted to go on indefinitely. It must stop. ${ }^{26}$

The tobacco companies indicated their views in a substitute proposal submitted in the form of a letter to the Secretary of Agriculture. These companies suggested an agreement of six provisions as outlined below:

(I) Each company was to purchase at least as much tobacco between September 25, I933 and March 3I, I934 as was used by such company during the fiscal period ending June 30,1933 .

(2) A minimum average price of $\mathrm{I} 7$ cents per pound was to be paid during the period by each buyer.

(3) Any deficit under the minimum price of $I 7$ cents was to be paid by buyers to the Secretary of Agriculture in proportion to the total value of buyers' purchases.

(4) Any sums so collected by the Secretary were to be distributed to the growers by the Secretary.

(5) Each buying company was to be required to submit reports to the Secretary of Agriculture on (a) its usings of flue-cured tobacco during the fiscal year, (b) the quantity purchased on auction markets during the specified period, and (c) the prices paid for flue-cured tobacco.

The sixth provision regarding the controversial issue of government control is here given in full:

This proposal is possible only on the basis-a condition of its acceptance and of the continuance of the obligation thereof-that insofar as the Agricultural Adjustment Administration has jurisdiction in the premises the undersigned companies are to manage, conduct and operate their respective businesses with freedom of business policy as heretofore, it being understood that no provision herein made in any way limits or restricts the authority of the Agricultural Adjustment Administration in the matter of the levying of processing taxes or prevents the negotiation and making of marketing agreements, not inconsistent with this paragraph, with respect to any other type of tobacco than that included herein.

${ }^{23}$ I bid. p. 129.

${ }^{23}$ Ibid. p. I16. 
The AAA held that it could not be bound by the above provision, while the tobacco companies believed it essential to have it incorporated in any agreement. They seemed to feel that the government was socialistically inclined and that it might take over the tobacco industry, or at least hinder it in its regular business operations, unless this provision was put in as a safeguard. The AAA seemed to feel that the companies were making a mountain out of a molehill but that the government could not contract away any power which might be necessary under the terms of the Adjustment Act.

For a time it appeared that the controversy raised on this section would keep the government and the tobacco companies from getting together. Steps were taken by the Tobacco Section to license tobacco buyers and, if and where necessary, to go on the auction markets and buy tobacco. ${ }^{27}$ The final agreement which became effective October 12 after much argument was a compromise between the proposed agreement of the government and the substitute proposal of the tobacco companies. Before the Secretary of Agriculture signed the agreement a group of leading tobacco grower: was called to Washington (October $\eta$ ) to indicate whether they were satisfied with it. "All but one answered affirmatively."

The agreement provided for the purchase by contracting buyers ${ }^{28}$ of at least 250 million pounds of flue-cured tobacco during the period from September 25, 1933, to March 3I, I934, at an average minimum price of 17 cents. $^{20}$ The buyers agreed not to "buy unduly of the high grades in order to defeat the purpose of this Agreement or concentrate ... purchases in any geographical region." Since the tobacco companies had acquired more than 75,000,000 pounds of flue-cured tobacco before September 25, the agreement indicated that the buyers would buy at least 75,000,000 pounds of tobacco more than had been used during the past fiscal year. However, their stocks were relatively low, due to the short 1932 crop.

In determining the average minimum price of 17 cents all purchases by contracting buyers were to be taken collectively. Any deficiency in price was to be made up by each contracting buyer paying the percentage of deficiency on the amount pur-

I Preparations were made immediately for the licensing of all buyers of flue-cured tobacco with the requirement that they pay not less than a specified minimum price for all their purchases. It was contemplated that tobacco for the export trade would be allowed a rebate in order not to disturb the export business. It was realized that it would probably be necessary, under the licensing of buyers, for the Administration to purchase considerable quantities of tobacco. Consequently, tentative arrangements were made for the handling of such purchases. Agricultural ADJustment, A Report of Administration of the Agricultural Adjustment Act, May, 1933 to February, 1934, p. 80.

${ }^{3}$ The contracting buyers were the American Tobacco Co., Liggett \& Myers Tobacco Co., R. J. Reynolds Tobacco Co., P. Lorillard Co., Philip Morris \& Co. Ltd. Inc., Larus \& Bro. Co., Continental Tobacco Co., and Brown \& Williamson Tobacco Corporation.

The exact amount was not stated in the agreement. The wording is as follows: "Each of the contracting buyers will purchase on the markets between September 25, 1933 and March 31, 1934, inclusive, a number of pounds of flue-cured tobacco of the 1933 crop at least equal to the number of pounds that it and all its subsidiaries and affiliates used of flue-cured tobacco (farm sales weight) in manufacturing business in the United States during the fiscal period comprising the twelve months ending June 30, x933." Tobacco Marketing Agreement, Pt. III, I (a). 
chased. In case the buyer did not buy his quota as fixed in the agreement he was liable to pay 17 cents per pound on the shortage.

The agreement contained a provision under which the prices of tobacco products were not to exceed the prices prevailing January 3, 1933 "by more than is made necessary by actual increase in production, replacement and invoice costs of merchandise, or by taxes or other costs resulting from action taken pursuant to the Act, since July I, 1933, and, in setting such price increases, to give full weight to probable increases in sales volume." Clearly this provision has little but moral teeth in it.

The agreement gave no assurance to the tobacco companies in the form of an explicit statement which had been required by them that the government would not interfere with their business operations. However, it was agreed that, "All information (unless it would have been otherwise legally obtainable by the Secretary without becoming his confidential information) obtained by or furnished to the Secretary pursuant to the foregoing provision ... if designated in writing as confidential when so obtained or furnished, shall remain the confidential information of the Secretary in accordance with the applicable General Regulations, Agricultural Adjustment Administration. Because of the limited purpose and duration of this Agreement, this clause shall not be considered as creating a precedent."30

The agreement, as finally accepted, was more in the form of a gentleman's agreement than the original draft prepared by the government for it left the matter of paying a satisfactory price to the growers largely up to the self-discipline of the tobacco companies. In general, the agreement accepted the companies' substitute plan for self-enforcement.

On the whole, the tobacco marketing agreement was well received by tobacco growers, but mention should be made of the very critical comment by Representative Frank Hancock of North Carolina. Mr. Hancock characterized the agreement as "a sop to the growers and a flop by the Agricultural Adjustment Administration. ... Though of course not intended, it amounts to the AAA placing its stamp of approval on existing conditions and present practices. It's the old deal warmed over and the true beneficiaries are continued as residuary legatees. The stark truth is that under its operations alone the grower will not get within hollering distance of parity prices for this year's crop." ${ }^{11}$

In view of the concern expressed by Mr. Hancock it is of significance that, although perhaps more could have been secured from the buyers, the marketing agreement has worked to the general satisfaction of tobacco growers. 'Tobacco

so Tobacco Marketing Agreement, Pt. II, 3, 6.

"Statcment given out Uctober 14 as published in Greensboro Daily News, October 22, 1933. Mr. Hancock had favored the government undertaking a stabilization program "which would have included standardization of grades to aid in getting rid of the hit-and-miss system of selling, minimum prices based on quality, and government contracts with independent dealers. Such a program could have been undertaken with a minimum risk to the government and would probably not have involved the purchase of more than $\$ 25,000,000$ worth of tobacco. . . . The government under this plan, would have bought only at the minimum parity price, and such purchases as it might have been required to make would have been subject to repurchase by the toisacco companies at the same price, plus the actual expense of handling." 
prices tended to stay at a satisfactory level after the agreement became effective. One factor which favored its success was the favorable exchange situation for export buyers who take more than half of the flue-cured crop. Although American prices under the agreement were higher than during the previous year, yet, when expressed in foreign money, they were little if any higher so that American tobacco was still relatively at a low price level. The export buyers during the hearings on the agreement indicated that they could coopperate on the "parity price" program if not included in the agreement, and as the first report of the AAA states: "Subsequent developments have demonstrated the soundness of their contention." 32 This leaves the interesting question as to whether the marketing agreement would have been so effective without favorable exchange rates.

\section{Problems in Preparing the Production Adjustment Contract}

The tobacco holiday movement in the flue-cured area which was followed by the lightning sign-up of more than 95 per cent of the flue-cured tobacco growers to a preliminary reduction contract placed the responsibility of preparing a flue-cured tobacco production adjustment contract squarely on the AAA. Dr. G. W. Forster who had assisted the AAA during July in drawing up a tentative program for fluecured tobacco was again called to Washington to proceed with the preparation of the contract. ${ }^{83}$ When the contract was finally approved by the AAA's legal division, it was presented in tentative form to the state meetings of agricultural extension workers who were charged with the responsibility of putting over the sign-up campaign. The suggestions from the field were incorporated in the final contract which was distributed on December 4 .

In preparing the flue-cured contract certain problems arose. The most important was to work out a basis for reduction that would be equitable to growers and which would confine production to approximately $500,000,000$ pounds. It was also essential that payments to producers be high enough to secure coöperation and yet be within the limits of the budget to be derived from the processing tax, which is limited by the amount of tobacco processed by domestic manufacturers. A further problem was to secure reduction by small growers without compelling them to produce uneconomically. Furthermore, a general reduction regardless of size of farm would effect small producers in the same way as a flat tax per unit of product for it would be regressive in effect. That is to say, a small producer would feel a production cut more. Another problem was raised by the fact that many producers had sold prior to the time that the marketing agreement had become effective in stiffening

a Agricultural adjustagent, A Report of Admanistration of tre Agricultural Adjustannt ACt, MAY, 1933, to February, 1934, p. 82.

"The Tobacco Section was assisted by the following tobacco farmers and agricultural workers during the formulation of the contract: North Carolina: John T. Thorne, Claude T. Hall, J. E. Winslow, G. M. Pate, Lionel Weil, E. Y. Floyd, Extention Tobacco Specialist, and Dean I. O. Schaub; South Carolina: J. T. Lazar, District Extension Agent, and L. M. Lawson; Virginia: J. R. Hutcheson, Director of Extension and J. L. Maxton, Assistant Agricultural Economist; Georgia: Homer Durden, and E. C. Westbrook, Extension Agronomist. 
prices. Finally, it was essential that the system of paying adjustment payments be economical, rapid, and equitable. The plan which was finally adopted, namely, to designate the trustees who would allocate adjustment payments to those having rights in the crop, was questioned on the ground that individuals could not handle government funds without being bonded. This object was avoided by arranging that the interested farmer would name the trustee and authorize the division of the payment-a plan which has proved generally satisfactory.

\section{Analysis of the Production Adjustment Contract}

Under the provisions of the flue-cured contract the growers agreed to limit their production in return for payments made by the AAA from proceeds of the processing tax. As a basis for the equitable operation of the scheme it was necessary to establish for each producer a base acreage and production as a "basis" to be used in determining the proper reduction in accordance with the terms of the contract. The producer was given the privilege of taking either his average acreage and production for r93I, 1932 and 1933; or 85 per cent of his average production for any two of these years; or 80 per cent of the production of 1933 ; or 70 per cent of the production of either I931 or 1932. The same period had to be chosen for determining the base acreage and the base production. By giving the producers a choice of base the contract recognized the impossibility of taking production conditions for any one year or for any average of years as a fair representation of growers' rights to produce. It was assumed that each grower had something comparable to an "inalienable right" to produce based upon his past performance. (As a matter of fact, the contract follows the land rather than the producer.) If acreage and yield in 1933 were taken as basic the producer who reduced in 1933 would be penalized in contrast to the producer who refused to accept government advice to reduce acreage. ${ }^{34}$ In some cases producers had cut down acreage for several of the past seasons. An average of three or five years as a base would tend to penalize those who had endeavored to keep the crop within economic bounds. The system of choices which was worked out may still penalize the farmer who conscientiously reduced his acreage during recent years in an effort to adjust his operations to the problem of over-supply, but the choices afford as fair a system of basing as could be worked out and still be practicable. The question of base production is exceedingly complex for crop production conditions have never been static. The method of determining the base has been looked upon only as a temporary expedient for use in arresting production.

The acreage and production allotments to each producer were determined by taking $7^{\circ}$ per cent of the base acreage and production. Thus if a producer's base acreage were I2 acres his acreage allotment would be 8.4 acres. If his base production were 8400 pounds his production allotment would be 5880 pounds.

The flue-cured contract provides for three kinds of payments to producers: (a)

${ }^{2}$ Many tobacco farmers had reduced their acreage 30 per cent as a condition to obtaining seed loans from the government. 
rental payments, (b) adjustment payments, and (c) equalizing payments. In addition a supplementary adjustment payment is provided to take care of the particular condition of the small producer who has a base acreage of less than 4 acres. Where share tenants and croppers have aided in the production of a crop, the adjustment and equalizing payments are to be made to a trustee for distribution. He is designated by the producer and his share tenants and croppers and may be the producer. ${ }^{36}$ The contract does not require the sharing of rental payments. A discussion of the various types of payments follows:

(a) Rental payments at the rate of $\$ 17.5^{\circ}$ per acre were to be paid to each producer for the acreage kept out of production. Payment was to be made between "December 15, 1933 and February 15, 1934, or not later than thirty (30) days from the date of acceptance of this contract." Assuming that the producer had a base acreage of 10 acres and that he was required to reduce acreage by $3^{\circ}$ per cent he would be paid a rental payment of $\$ 52.50(3 \times \$ 17.50)$. The contract provided that the producer could use the rented acres only as follows: All or any part could be left idle or planted to pasture; one-half could be planted to feed crops for home consumption or use on the farm. In order to protect the interest of those who were coöperating on production control programs for other crops the contract also provided that the producer would not increase in 1934 and/or I935, as contrasted with r932 or 1933 , the acreage planted to crops to be harvested or the production for sale of wheat, cotton, field corn, rice, other types of tobacco, hogs, or milk and its products.

(b) Adjustment payments are made after the crop has been harvested and the producer's "marketing card" is accepted by the Secretary. ${ }^{38}$ The amount of the adjustment payment is fixed at $121 / 2$ per cent of the net value of the initial production allotment. The net value of the initial production allotment is the estimated production of the allotted acreage at the price at time of sale. However, the price used in computing the net value of the initial production allotment is limited to 2 I cents per pound. Moreover, in case the quantity produced for market is less than the. initial production allotment the producer receives 2 cents per pound for each pound of the deficiency. Illustrations I, II, and III show the method of computing these payments.

\footnotetext{
${ }^{33}$ Paragraph 23 of the contract provides as follows: "In the event that such tobacco is produced with the aid of share tenants and/or share croppers each adjustment payment shall be paid to the producer if designated as trustee (or to such other person as may be designated as trustec) by the producer and such share tenants and share croppers on this farm as have at the time of such designation an interest in the tobacco produced on this farm in 1934 or in the proceeds therefrom. . . . Said trustee shall distribute such payment to those so designating him as a trustec, as their interests may appear, in the same proportion as 'the net market values of the respective shares of such persons in the tobacco produced on this farm in 1934 bear to the net market value of the total amount of such tobacco."

Price equalizing payments are to be distributed in the same manner. The distribution difficulties encountered under the cotton contracts where no such trustee provision was employed are discussed in Bruton, supra, p. 000 .

8s "The "Marketing Card" is to serve as record of sales and is to be filled out by the warchouseman at the time of sale.
} 
Illustration 1 .

With an initial production allotment of 7,000 pounds and an average net market price of 16 cents per pound the "net value of the initial production allotment" is $\$ 1,120$. Since the percentage for determining the adjustment payment is $12 \frac{1}{2}$, the amount of the adjustment payment is $\$ 140$.

\section{Illustration II.}

With an initial production allotment of 7,000 pounds and an average net market price of 22 cents per pound or one cent more than the maximum which may be used in determining the net value of the initial production allotment, the "net value of the initial production allotment is $\$ \mathrm{r}, 47 \mathrm{O}(7,000 \times \$ 0.2 \mathrm{I})$. Since the percentage for determining the adjustment payment is $121 / 2$ per cent the amount of the adjustment payment is $\$ 183.75$.

\section{Illustration III.}

With an initial production allotment of 7,000 pounds but with a quantity produced for market of only 5,000 pounds, the market value of tobacco sold with assumed price at 16 cents is $\$ 800$. The amount of the adjustment payment on amount sold is thus $\$ 100(121 / 2 \times 800)$. However, the deficiency in quantity produced under the initial production allotment is 2,000 pounds. The payment on the deficiency is $\$ 40(2,000$ pounds at 2 cents) so that the total adjustment payment is $\$ 40$.

A special supplementary adjustment payment is provided for small growers with a base acreage of less than 4 acres. In these cases the percentage used in determining the adjustment payment is increased above $121 / 2$ per cent by $1 / 2$ per cent for each tenth acre by which the base tobacco acreage is less than 4 acres. The percentage used is however limited to 25 per cent, so that where base acreage is lower than I.4 acres no higher percentage is paid on adjustment payment. Illustration IV makes this payment clear.

\section{Illustration IV.}

With a base tobacco acreage of 3 acres and an initial production allotment of 2,roo pounds, the net value of the initial production allotment at an average net market price of $\mathrm{I} 6$ cents per pound is $\$ 336$. Since for every $\mathrm{I} / \mathrm{ro}$ acre that the base is below 4 acres the adjustment payment is increased by $1 / 2$ per cent, the adjustment payment is increased from $12 \frac{1}{2}$ per cent to $17 \frac{1}{2}$ per cent. The amount of the adjustment payment is therefore $\$ 58.80\left(17^{1 / 2} \times 336\right)$.

(c) In addition to rental and adjustment payments and supplementary adjustment payments for small growers the contract provided for price equalization payments for the I933 crop. The price equalization payments were intended to equalize prices for contract-signing growers for the I933 crop. The records of tobacco companies clearly indicated that two distinct price jumps occurred before tobacco reached 
the level of prices stipulated in the marketing agreement. Paragraph 20 therefore provides that:

If the producer sold all or any part of his 1933 crop from this farm through an auction warehouse market prior to and including October 28, 9933 there shall be paid for the benefit of the producer and such share tenants and/or share croppers as had an interest in such tobacco, a price-equalizing payment on the net proceeds from the producer's original sales of such tobacco, provided application is duly made in accordance with a form to be provided by the Secretary. Said price-equalizing payment shall be twenty per cent $(20 \%)$ of such net proceeds from such tobacco so sold from August I, r933, to September I, 1933, inclusive, and ten per cent (ro\%) of such net proceeds from (r) such tobacco (other than that sold on the South Carolina and Border markets) so sold from September 25, $x 933$ to October 7, 1.933 inclusive, and (2) from such tobacco so sold on the South Carolina and Border markets from September 25, I933 to October 28, I933, inclusive. This payment shall be made within sixty (60) days after the application for same has been approved by the Secretary.

\section{Revision and Clarufication of Contract}

As the campaign for signatures to the production adjustment contract progressed it was found necessary to clarify certain provisions of the contract by administrative rulings.

The following ruling was designed to explain more fully the section in the contract relative to the status of share tenants and share croppers under the terms of the contract: "A producer agrees under the terms of a Tobacco Production Adjustment Contract not to reduce the number of share-tenants and/or share-croppers engaged in growing tobacco on his farm in 1934 below the number so engaged in growing tobacco in 1933, because of the reduction in tobacco acreage and tobacco production, or because of óther provisions of the contract."

Other rulings related to such matters as the method of handling tobacco contracts for farms sold prior to the date of acceptance of the contracts; the procedure for handling checks and official forms used in connection with rental and price-equalizing payments; the manner in which rented acres could be used so as to be considered as "planted to soil improving or erosion-preventing crops."

However, in Administrative Ruling No. 23, released May II, 1934, because of unfavorable weather conditions in the flue-cured tobacco belt and improved condi. tions of demand, a basic change in the operation of the contract was provided for. The contract had provided that the initial production allotment might be adjusted at the discretion of the Secretary not later than August, r934, depending upon the prospective yield and demand conditions for the crop year 1934 , provided that the adjusted production allotment would not be less than seventy per cent $(70 \%)$ of the base tobacco acreage.

Administrative Ruling No. 23 allowed producers to raise their acreage from $7^{0}$ per cent of the base period to 80 per cent, and provided for decreasing the adjustment payment by fixed percentages if the grower should produce more than 70 per cent of the base tobacco production. The effect of this ruling simply was to allow producers 
to produce 80 instead of 70 per cent of their base acreage and production. Under the ruling producers taking advantage of it would receive smaller payments than those who grew and marketed only $7^{\circ}$ per cent of their base. The ruling also provided for increasing the adjustment payment by $1 / 2$ of one per cent for each tenth of an acre where the base acreage is less than four acres. Dr. Hutson commented on this ruling when it was issued as follows: ". . . the ruling demonstrates the flexibility of the adjustment program in adapting itself to changes which may occur. ... No doubt, many growers will find it to their advantage to continue with the reduction originally planned and receive the larger rental and adjustment payments. Perhaps as many or more will find it to their advantage to grow and market 80 per cent of their base production, and accept the reduced payments."

\section{The Sign-up Campaign}

The campaign to get the signatures of flue-cured tobacco growers on the production control contracts was formally opened on December 4, 1933. Final campaign plans and instructions were considered at meetings of county agents, extension workers and AAA officials. In each county a group of local committeemen comprised of tobacco growers was selected by the county agent to serve as direct contact men with farmers. The county agent acted as the representative of the AAA Tobacco Section and as a liaison agent between individual farmers and the Section.

During the cotton acreage reduction campaign in the summer of 1933 and the preliminary sign-up campaign for tobacco it had been the practice to make a thorough canvass of all farmers who had not voluntarily signed the contract. This method had proved to be expensive, and it had developed a feeling among farmers that they would be called on personally. The agents were therefore advised that committeemen were not to visit each farmer for the purpose of inducing him to sign a flue-cured tobacco contract. Instead, the farmer was to come to the county agent's office or to some other designated place. In the majority of the counties local committeemen set up temporary offices in each community center for the purpose of filling out contracts. Some member of the committee was at this place at all times.

As fast as the contracts were filled out and signed by the individual farmers and at least two local committeemen, they were turned over to the county committee for their approval and signature. Following the approval of the county committee contracts were turned over to the county agent to be checked for accuracy and reasonableness. ${ }^{37}$ Upon his approval the information regarding acreage and production was transferred to a special form which was sent to the State Office for final approval.

The contracts provided for a statement of total acreage planted and total production for the years I931, 1932, and 1933. These figures were the sole basis for determining base acreage and base poundage, and it was most important that they be accurate.

\footnotetext{
${ }^{27}$ This methor was not followed in all cases. For instance, some agents handled the major portion of the sign-up in their offices with the local committeemen working with them on individual contracts. In other cases the sign-up was conducted by local committeemen with the guidance of the county agents.
} 
At the time of filling out the contract the farmer was asked to state his acreage and production and supply evidence that his statements were correct. In only a relatively small number of cases were farmers able to supply evidence of acreage and production over a period of three years. Each contract had to be examined by some committeeman who knew the farmer personally and had some knowledge of the statements made. The problem of overrun had been anticipated, and the county agents had requested average production figures as a check..$^{38}$. In cases where there was doubt as to the honesty of a farmer's statement and conclusive evidence could not be produced the contracts were reduced to the county average or very close to it by the county committee. A close check was maintained by the State Office, and as a result the agents were warned that it was very important that the contracts be held in line with official figures. ${ }^{39}$ As the campaign progressed more attention was devoted to the accuracy of acreage and production figures, and in most cases farmers filed evidence of their 1933 production.

The problem of adjusting contracts to agree with official figures was a longdrawn-out process. Early in the sign-up campaign it was evident that acreage and production figures were being over-estimated by farmers. In the meantime the Tobacco Section was working on a set of official county figures to be used in adjusting contracts. Much time was consumed in arriving at these figures, and it was not until March 3, I934, that county agents in North Carolina were given the official allotment of acreage and production.

These figures as reported by farmers were considerably in excess of the official allotments throughout the flue-cured area, and the discrepancy between official and contracted figures created a serious problem for the county committees and county agents. While growers had agreed to accept adjustments in acreage and production, many were reluctant to consider further adjustments. In North Carolina the average over-run for the three year period (1931-x933) was 6.5 per cent for acreage and 16.7 per cent for production. ${ }^{40}$ The tendency for farmers to report high acreage and high

${ }^{33}$ In North Carolina tables showing acreage and production for each county in $x 931$ and 1932 and the probable acreage and production in 1933 , together with the average for the three years, had been sent out to each agent in September, for use in checking preliminary contracts, and these figures were used in checking contracts in the final sign-up campaign.

${ }^{20}$ The following letter was sent to county agents in North Carolina on December 28, 1933: "The contracts coming in from some counties are showing average acre yields much above the county threeyear averages accepted by Washington. The contract figures will have to be brought in line or growers who cannot furnish proof will have to take a horizontal cut in order to bring the county average down. It will be much more satisfactory to get your contracts right to begin with. Each county will be calculated as a separate unit and without reference to a State average."

${ }^{+0}$ The percentage variation in acreage and production reported by farmers over the official state figures for the years I931, 1932, and 1933 were as follows for North Carolina:

\begin{tabular}{|c|c|c|c|c|c|c|}
\hline Year & $\begin{array}{l}\text { Acreage } \\
\text { Reported on } \\
\text { Contracts }\end{array}$ & $\begin{array}{c}\text { Official } \\
\text { Estimate of } \\
\text { Acreage }\end{array}$ & $\begin{array}{l}\text { Per Cent } \\
\text { Overrun }\end{array}$ & $\begin{array}{l}\text { Production } \\
\text { Reported on } \\
\text { Contracts }\end{array}$ & $\begin{array}{l}\text { Official } \\
\text { Estimate of } \\
\text { Production }\end{array}$ & $\begin{array}{l}\text { Per Cent } \\
\text { Overrun }\end{array}$ \\
\hline $1931 \ldots \ldots \ldots$ & 768,554 & 690,500 & 10.16 & $602,021,245$ & $473,957,000$ & 26.1 \\
\hline $\begin{array}{l}1932 \ldots \ldots \ldots \ldots \\
\text { I933 . . . . . . } \\
\text { Average . . . . }\end{array}$ & $\begin{array}{c}527,456 \\
672,050 \\
\ldots \ldots\end{array}$ & $\begin{array}{c}464,500 \\
685,000 \\
\ldots \ldots\end{array}$ & $\begin{array}{l}11.94 \\
1.90^{\circ} \\
6.50\end{array}$ & $\begin{array}{c}392,120,157 \\
554,355,46 \mathrm{r} \\
\ldots \ldots \ldots \ldots\end{array}$ & $\begin{array}{r}289,606,000 \\
527,000,000 \\
\ldots \ldots \ldots \ldots\end{array}$ & $\begin{array}{r}4.93 \\
16.70\end{array}$ \\
\hline
\end{tabular}

- 1933 acreage as reported by farmers was $r .90$ per cent less than the official estimate acreage. 
production was much less for the recent year, where checking data were available.

The process of bringing farmers' figures into line created much comment throughout the flue-cured area. Small producers felt that additional cuts were not justified and that large producers should bear most of the burden. In North Carolina a meeting of county agents and county committeemen was called for the purpose of discussing plans for the "scale-down." Each county was given the job of handling its own adjustment: Several methods for adjustment were possible. Each county could decide whether a horizontal cut should be applied to all contracts or whether individual adjustments should be made, or whether a combination of individual adjustments and a horizontal cut could be worked out.

'The campaign for reduction was generally successful throughout the flue-cured area. While the enthusiasm that was manifest during the preliminary campaign did not continue to prevail because higher prices caused many to lose interest, yet the farmers felt obligated since they had signed the previous agreements which had been effectively used to better prices. Approximately roo,000 contracts, representing about 98 per cent of the growers, were signed in the five flue-cured tobacco states during the period December 4-April r.

\section{UNSETTLED IsSUES}

There is no question but that the flue-cured tobacco production adjustment program combined with the effect of the marketing agreement has greatly improved the economic and social condition of flue-cured tobacco growers. Whereas the 1932 crop brought flue-cured farmers approximately $\$ 41,992,000$ the 1933 crop has been marketed for approximately $\$ 112,000,000$. In addition, flue-cured producers who have entered into adjustment contracts will secure approximately $\$ 8,600,000$ prior to the time of marketing the 1934 crop in the form of rental, adjustment, and equalizing payments. The flue-cured tobacco belt has been changed during the past year from an area of despondency to one of optimism. However, the program to date has been of an emergency character. Assuming that some kind of control program of planned production is to be carried on in the future, there are many unsettled issues.

The Kerr Bill, ${ }^{41}$ like the Bankhead Cotton Control Act, ${ }^{42}$ would heavily tax production of non-contract signers. This raises the issue of compulsory production control as opposed to the voluntary plan now being used. Advocates of this measure believe that if it is not adopted those who have coöperated on the adjustment program may become dissatisfied if non-signers tend to benefit by their action.

Many believe that a marketing agreement similar to the one effective during 1933 should be immediately planned for the 1934 season. This raises the question whether the tobacco companies should be expected to pay higher prices voluntarily next season because of the restricted production. Dr. Forster has urged through the news-

¿ [Since the completion of this article, the Kerr Bill has been enacted, Act of June 28, 1934, No. 483 , 73rd Cong., 2nd Sess. It is described in Cavers, Production Control by Taxation, infra, p. 349.]

Act of April 21, 1934, Public, No. 169, 73rd Cong., 2nd Sess. 
papers of North Carolina that steps be taken on this matter immediately instead of waiting to see what will happen.

An interesting question is also raised if the present type of production adjustment program is to be carried on in the future. The present program is based simply on restricting production as fairly as possible. The present base period can hardly be recommended without change for years in the future. This would perpetuate the existing rights to produce tobacco regardless of social and economic changes. If the agricultural industry is to be dynamic, rights to produce tobacco or any other crop must be subject to future considerations and not be based simply on the existing organization of the agricultural industry. It is of interest that the AAA has considered the advisability of providing for one contract to cover all commodities subject to an adjustment program and that it is considering plans for planned agricultural production by type of farming areas.

The present program has so far made no provision for improvement of basic marketing machinery for the flue-cured tobacco crop. Dr. Hutson referred to this matter in an address delivered January to to the Kentucky Farm Bureau Federation: "At present we are greatly concerned with some of the existing inefficiency in the conducting of essential operations of such things as marketing the producers' crop and distribution of the finished product." Later in the same address he said: "I do not feel that the farmers should be asked over a long period to bear the cost of an inefficient arrangement for selling." This problem will have to be considered in dèveloping a long-time program for the flue-cured industry. It may be that farmers can develop coöperative associations that will integrate marketing practices with a planned program of acreage adjustment. Such associations could function both in building a system of grower-controlled marketing machinery and in sponsoring production adjustment. Developments of this sort will no doubt depend upon whether the existing marketing system renders satisfactory service in the future. 